\title{
KONTRIBUSI USAHATANI PADI SAWAH TERHADAP PENDAPATAN KELUARGA DI KELURAHAN TARATARA SATU KECAMATAN TOMOHON BARAT KOTA TOMOHON
}

Olivia Bulanta

Elsje Pauline Manginsela

Welson Marthen Wangke

\begin{abstract}
The purpose of this research is to find out how large the rice farming is contributed to family income. The research was conducted in December 2018 to January 2019, ranging from preparation to research Report preparation. The data used in this study are primary data and secondary data. Primary Data is derived from a direct interview with the respondent's farmer. Secondary Data is obtained from the village office of Taratara One, and internet through Google Books and Google scholars to obtain articles of journal and thesis related to the topic of the research that is contribution of rice field farming to Family income. The sampling method was done intentionally with a total of 25 respondents. The analysis used in this study was a descriptive analysis and used the formula contributions as well as presented in the form of tables. The results showed that rice farming was an average contribution of $22.29 \%$ on family income. ${ }^{* p r m *}$
\end{abstract}

Keywords: Contribution, rice farming paddy, income family.

\begin{abstract}
ABSTRAK
Tujuan penelitian ini adalah untuk mengetahui berapa besar kontribusi usahatani padi sawah terhadap pendapatan keluarga. Penelitian ini dilaksanakan pada bulan Desember 2018 sampai bulan Januari 2019, mulai dari persiapan hingga penyusunan laporan penelitian. Data yang digunakan dalam penelitian ini adalah data primer dan data sekunder. Data primer diperoleh dari dari wawancara langsung dengan petani responden. Data sekunder diperoleh dari Kantor Kelurahan Taratara satu, dan internet melalui google books dan google scholars untuk mendapatkan artikel jurnal dan skripsi yang berkaitan dengan topik penelitian ini yaitu kontribusi usahatani padi sawah terhadap pendapatan keluarga. Metode pengambilan sampel dilakukan secara sengaja dengan jumlah responden sebanyak 25 orang. Analisis yang digunakan dalam penelitian ini adalah analisis deskriptif dan menggunakan rumus kontribusi serta disajikan dalam bentuk tabel. Hasil penelitian menunjukkan bahwa usahatani padi sawah memberikan kontribusi rata-rata sebanyak 22,29\% pada pendapatan keluarga. ${ }^{*}$ eprm*
\end{abstract}

Kata kunci : Kontribusi, Ushatani Padi Sawah, Pendapatan, Keluarga. 


\section{PENDAHULUAN}

\section{Latar Belakang}

Indonesia dikenal sebagai negara agraris di mana sebagian besar penduduknya memiliki mata pencaharian utama di bidang pertanian termasuk padi sawah. Untuk itu usaha tani padi sawah di harapkan dapat memberikan kontribusi pendapatan untuk mencukupi kebutuhan rumah tangga petani sehari-hari. Penelitian ini ingin mengetahui berapa besa kontribusi usaha tani padi sawah terhadap pendapatan keluarga. Usahatani padi sawah berkontribusi besar dalam pendapatan keluarga petani.

Pertanian di Indonesia menjadi salah satu agenda utama pengembangan dari pembangunan yang berkelanjutan. Sektor pertanian merupakan sektor yang paling penting dalam struktur perekonomian Negara. Terdapat beberapa alasan yang medasari pentingnya pertanian di Indonesia yaitu potensi sumberdayanya yang besar dan beragam, memberikan sumbangan terhadap pendapatan nasional cukup besar, jumlah penduduk yang menggantungkan hidupnya pada sektor ini besar, dan menjadi basis pertumbuhan di pedesaan (Pratama, 2011).

Sebagian orang mengartikan Pertanian sebagai kegiatan manusia dalam membuka lahan dan menanaminya dengan berbgai jenis tanaman, baik tanaman semusim maupun tanaman tahunan, tanaman pangan maupun nonpangan (Suratiyah, 2006). Padi masih merupakan komoditas strategis yang memiliki sensitivitas tinggi dari aspek politis, ekonomi, dan kerawanan sosial, karena padi adalah pangan pokok lebih dari 95 persen penduduk (Suryana, 2005).

\section{Usahatani}

Usahatani merupakan kegiatan seseorang mengalokasikan sumberdaya yang secara efektif dan efisien dengan tujuan memperoleh keuntungan yang tinggi pada waktu tertentu (Hatidja, 2008). Dikatakan efektif apabila petani atau produsen dapat mengalokasikan sumberdaya yang mereka miliki atau yang dikuasai sebaik-baiknya dan efisien bila pemanfaatan sumberdaya tersebut menghasilkan keluaran (output) yang melebihi masukan (input).
Usahatani merupakan setiap kombinasi yang tersusun dari alam, tenaga kerja dan modal yang ditunjukan pada pada produksi sektor pertanian. Sesuai dengan batasannya maka pada setiap unsur usahatani selalu ada unsur alam, tenaga kerja dan modal yang beragam dan pengelolaannya dilakukan oleh petani (Lewa, 2014).

\section{Tujuan Usahatani}

Tujuan suatu usahatani yang dilaksanakan oleh rumah tangga petani mempunyai pengaruh yang sangat besar terhadap pengambilan keputusan dan tindakan yang akan diambil, maupun terhadap pandangan rumah tangga akan berlangsung dan kemampuannya dalam menerima berbagai pembaharuan termasuk teknologi pertanian. Usahatani yang dilakukan oleh rumah tangga umumnya mempunyai dua tujuan yaitu mendapatkan keuntungan maksimal atau untuk keamanan dengan meminimalkan resiko, termasuk keinginan untuk memiliki persediaan pangan yang cukup untuk konsumsi rumah tangga dan selebihnya untuk dijual (Soedjana 2007).

Untuk mencapai tujuan tersebut, petani selalu memperhitungkan untung ruginya walau tidak secara tertulis. Artinya petani membandingkan antar hasil yang diharapkan akan diterima pada waktu panen (Isaskar, 2014).

\section{Konsep Penerimaan}

Penerimaan usahatani yaitu dari sumber usahatani meliputi nilai penjualan hasil, penambahan jumlah inventaris, nilai produk yang dikonsumsi petani dan keluarga. Penerimaan adalah hasil perkalian antara produksi yang diperoleh dengan harga jualnya (Hernanto, 1993).

Secara sistematis dapat di tulis dalam bentuk sebagai berikut :

$$
\mathrm{TR}=\mathrm{Y} 1 \quad \mathrm{X} \quad \text { Pyi }
$$

\section{Dimana :}

$$
\begin{aligned}
& \mathrm{TR}=\text { total revenue (penerimaan) } \\
& \mathrm{Y} 1=\text { output }(\text { jumlah produksi padi) } \\
& \mathrm{Pyi}=\text { price }(\text { harga padi) }
\end{aligned}
$$




\section{Pendapatan Petani}

Pendapatan adalah jumlah penghasilan yang diterima oleh penduduk atas prestasi kerjanya selama satu periode tertentu, baik harian, mingguan, bulanan, maupun tahunan (Sukirno 2006).). Kegiatan usaha pada akirnya akan memperoleh pendapatan berupa nilai uang yang diterima dari penjualan produk yang dikurangi biaya yang telah dikeluarkan.

\section{Rumusan Masalah}

Berdasarkan latar belakang di atas, maka yang menjadi masalah dalam penelitian ini adalah Berapa besar kontribusi usahatani padi terhadap pendapatan keluarga di Kelurahan Taratara Satu, Kecamatan Tomohon Barat, Kota Tomohon?

\section{Tujuan Penelitian}

Tujuan dari penelitian ini adalah untuk mengetahui berapa besar kontribusi uasahatani padi terhadap pendapatan keluarga di Kelurahan Taratara Satu, Kecamatan Tomohon Barat, Kota Tomohon.

\section{Manfaat Penelitian}

Manfaat yang dapat diperoleh dari penelitian ini :

1. Penelitian ini dapat memberikan manfaat yang baik sebagai bahan informasi tentang kontribusi usahatani padi terhadap pendapatan keluarga di Kelurahan Taratara Satu, Kecamatan Tomohon Barat, Kota Tomohon, Serta sebagai pertimbangan.

2. Masukan bagi pemerintah Kota Tomohon

3. Bisa menjadi referensi bagi peneliti selanjutnya.

\section{METODE PENELITIAN}

\section{Waktu dan Tempat Penelitian}

Penelitian ini telah dilaksanakan selama 3 bulan terhitung dari bulan Desember 2018 sampai bulan Februari 2019, sejak persiapan hingga penyusunan laporan hasil penelitiaan. Penelitiaan dilaksanakan di Kelurahan Taratara Satu, Kecamatan Tomohon Barat, Kota Tomohon.

\section{Metode Pengumpulan Data}

Metode pengumpulan data dilakukan dengan metode sensus dengan jumlah responden 25 petani. Data yang digunakan yaitu data primer diperoleh melalui wawancara langsung dengan petani responden berdasarkan pertanyaan yang telah disusun dalam bentuk kuesioner dan Data sekunder diperoleh dari instansi yang terkait dengan penelitiaan ini.

\section{Metode Pengambilan Sampel}

Penentuan lokasi pengambilan sampel dilakukan secara sengaja, yaitu di Kelurahan Taratara Satu, Kecamatan Tomohon Barat, Kota Tomohon. Penelitiaan ini diambil berdasarkan jumlah petani yang mengusahakan usahatani padi dengan jumlah 25 petani.

\section{Konsep Pengukuran Variabel Penelitiaan}

Batasan variabel yang diteliti adalah sebagai berikut:

1. Luas Lahan, yaitu jumlah luas keseluruhan lahan yang digunakan untuk usahatani padi (ha)

2. Jumlah produksi, hasil yang diperoleh petani dalam satu kali panen $(\mathrm{kg})$

3. Harga jual yang berlaku ditingkat petani $(\mathrm{Rp} / \mathrm{kg})$

4. Biaya usahatani padi, yaitu biaya yang dikeluarkan selama proses produksi :

a. Biaya tetap (fixed cost)
1. Sewa lahan
2. Pajak lahan
3. Iuran Air Irigasi
4.Peyusutan Alat

b. Biaya tidak tetap (variable cost)

I. Biaya sarana produksi ( $\mathrm{Rp})$
a. Bibit $(\mathrm{Rp} / \mathrm{kg})$
b. Pupuk $(\mathrm{Rp} / \mathrm{kg})$
c. Pestisida $(\mathrm{Rp} / \mathrm{kg})$

II. Biaya tenaga kerja (Rp)

III. Sewa alat

5. Pendapatan usahatani padi yaitu, selisih antara penerimaan dengan biaya yang di keluarkan (Rp) 
6. Pengeluaran usahatani lain yaitu, seluruh biaya yang dikeluarkan selama proses produksi (Rp)

7. Pendapatan usahatani lain yaitu, pendapatan usahatani diluar usahatani padi, diperoleh dari selisih antara penerimaan dengan pengeluaran $(\mathrm{Rp})$

8. Pendapatan diluar petani yaitu, jumlah pendapatan dari berbagai sumber (Rp)

9. Total pendapatan yaitu, jumlah keseluruhan pendapatan yang diperoleh dari pendapatan usahatani padi sawah diluar pertanian ( $\mathrm{Rp}$ )

10. Kontribusi pendapatan, sumbangan atau bagian pendapatan usahatani padi terhadap total pendapatan keluarga (\%)

11. Karakteristik petani :
a) Umur petani (Tahun)
b) Tingkat pendidikan (SD, SMP, SMA, Perguruan Tinggi)
c) Jumlah anggota keluarga (orang)

Disajikan dalam bentuk tabel. Untuk menghitung pendapatan digunakan rumus analisis pendapatan usahatani.

\section{Analisis Data}

Analisis data yang digunakan dalam penelitiaan ini adalah analisis deskriptif dan disajikan dalam bentuk tabel. Untuk melihat tingkat keuntungan ekonomis padi sawah akan digunakan analisis penerimaan, biaya, pendapatan.

Penerimaan Usahatani adalah perkalian antara produksi yang diperoleh dengan harga jual. Pernyataan ini dapat ditulis sebagai berikut.

$$
\mathrm{TR}=\mathrm{Y} 1 \times \mathrm{Pyi}
$$

Dimana :

$\mathrm{TR}=$ total revenue (total penerimaan)

$\mathrm{Y} 1$ = output (jumlah produksi padi)

Pyi $=$ price (harga padi)

Untuk mengetahui besarnya kontribusi pendapatan padi maka digunakan

Rumus:

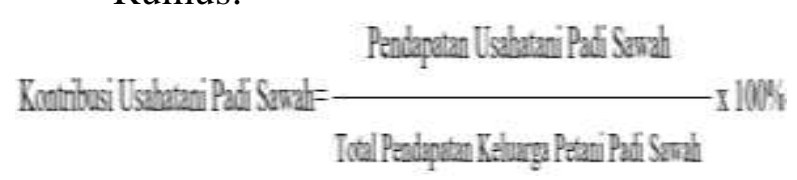

\section{HASIL DAN PEMBAHASAN}

\section{Kondisi Umum Kelurahan Taratara Satu}

\section{Batas Wilayah}

Kelurahan Taratara Satu merupakan salah satu kelurahan di Kota Tomohon tepatnya di Kecamatan Tomohon Barat. Kelurahan Taratara Satu berbatasan dengan:

Sebelah Utara berbatasan dengan: Kelurahan Taratara dan Taratara Dua

Sebelah Selatan berbatasan dengan: Kelurahan Tincep dan Desa Pinaras

Sebelah Timur berbatasan dengan :

Kelurahan Taratara Dua dan Woloan Tiga

Sebelah Barat berbatasan dengan :

Kelurahan Taratara dan Ranotongkor

Kelurahan Taratara Satu, terbagi atas 8 (Delapan) Lingkungan, dengan luas wilayah Sebesar 645,25 Ha (Kantor Kelurahan Taratara Satu Data Kelurahan Desember 2016) yang meliputi :

$\begin{array}{ll}\text { Pemukiman } & : 15 \mathrm{ha} / \mathrm{m}^{2} \\ \text { Lahan Sawah } & : 200 \mathrm{ha} / \mathrm{m}^{2} \\ \text { Lahan Perkebunan } & : 125 \mathrm{ha} / \mathrm{m}^{2} \\ \text { Lahan Pekarangan } & : 2,50 \mathrm{ha} / \mathrm{m}^{2} \\ \text { Hutan } & : 100 \mathrm{ha} / \mathrm{m}^{2}\end{array}$

Keadaan Topografi Kelurahan Taratara Satu berdataran rendah, berkawasan rawah dan dilalui oleh aliran sungai dengan kondisi iklim yang sejuk karena kelembapan udara sekitar $75 \%$ (persen) dan suhu rata-rata $25-35^{\circ} \mathrm{C}$.

\section{Keadaan Penduduk}

Kelurahan Taratara Satu memiliki jumlah penduduk yaitu 1813 jiwa dengan jumlah keluarga 493 kk. Komposisi penduduk Keluarahan Taratara Satu dapat dilihat pada Tabel 1.

Tabel 1. Jumlah penduduk Kelurahan Taratara Satu Berdasarkan Jenis Kelamin

\begin{tabular}{lcc}
\hline \multicolumn{1}{c}{ Jenis Kelamin } & Jumlah Responden & Persentase (\%) \\
\hline Laki-laki & 953 & 52,57 \\
Perempuan & 860 & 47,43 \\
\hline Jumlah & 1813 & 100,00 \\
\hline
\end{tabular}

Sumber: Diolah dari Data Sekunder 2016 


\section{Mata Pencaharian}

Jenis mata pencaharian yang dikerjakan masyarakat di Kelurahan Taratara tepatnya di Kecamatan Tomohon Barat dapat dilihat pada Tabel 2.

Tabel 2. Struktur Mata Pencaharian Menurut Sektor

\begin{tabular}{lccc}
\hline $\begin{array}{l}\text { Sektor Mata } \\
\text { Pencaharian }\end{array}$ & $\begin{array}{c}\text { Jumlah Pemilik } \\
\text { usaha (orang) }\end{array}$ & $\begin{array}{c}\text { Jumlah } \\
\text { pemilik usaha } \\
\text { Perorangan }\end{array}$ & $\begin{array}{c}\text { Jumlah } \\
\text { Buruh/Karyawan } \\
\text { Pengupul (orang) }\end{array}$ \\
\hline Pertanian & 312 & 285 & 21 \\
Perkebunan & 100 & 50 & 0 \\
Peternakan & 15 & 15 & 60 \\
Perikanan & 10 & 10 & 0 \\
Kehutanan & 10 & 10 & 60 \\
Pertambangan & 1 & 1 & 2 \\
Perdagangan & 2 & 2 & 10 \\
\hline Jumlah & 450 & 374 & 153 \\
\hline Daftar Isian Tingkat Perkembangan Desa dan Kelurahan Tahun 2016
\end{tabular}

Karakteristik Usahatani Berdasarkan Luas Lahan

Luas lahan sangat berpengaruh terhadap jumlah produksi usahatani padi sawah. Luas lahan juga menentukan jumlah pemakaian pupuk maupun obat-obatan yang akan digunakan oleh petani. dilihat pada Tabel 3 .

Tabel. 3 Luas Lahan Petani Responden

\begin{tabular}{lcc}
\hline Luas Lahan $(\mathrm{Ha})$ & Jumlah (Responden) & Persentase $(\%)$ \\
\hline$<0,5$ & 5 & 20,00 \\
$0,5-1$ & 18 & 72,00 \\
$>1$ & 2 & 8,00 \\
\hline Jumlah & 25 & 100,00 \\
\hline \multicolumn{2}{l}{ Sumber: Diolah dari Data Primer 2018 }
\end{tabular}

Tabel 3 menunjukkan bahwa luas penguasaan lahan tersempit yang dikuasai oleh responden sebesar 0,4092 ha. Sedangkan luas penguasaan lahan terluas sebesar 1,5 ha. Rata-rata luas penguasaan lahan oleh responden sebesar 0,5-1 ha Tabel 2, menunjukkan bahwa sebagian besar responden memiliki luas lahan $0,5-1$ ha 18 $(72 \%)$ responden.

\section{Status Kepemilikan Lahan}

Status kepemilikan lahan yang digarap oleh petani responden di Kelurahan Taratara Satu menentukan besar kecilnya penerimaan dan biaya serta pendapatan yang akan diterima oleh petani. Status kepemilikan lahan dapat dilihar pada Tabel 4.

Tabel 4. Status Kepemilikan Lahan

\begin{tabular}{lcc}
\hline Status Kepemilikan & Jumlah (Responden) & Persentase (\%) \\
\hline Pemilik & 6 & 24,00 \\
Penggarap & 18 & 72,00 \\
Penyewa & 1 & 4,00 \\
\hline Jumlah & 25 & 100,00 \\
\hline Sumber: Diolah dari Data Primer 2018 &
\end{tabular}

Status pengusaan lahan terkecil dikuasai oleh penyewa dengan jumlah responden 1 $(4, \%)$. Sedangkan status penguasaan lahan terbesar dikuasai oleh penggarap dengan jumlah responden 18 (72). Rata-rata penguasaan lahan dikuasai oleh penggarap dengan Persentase $72 \%$. Tabel 3, status kepemilikan lahan petani responden sebagian besar yaitu penggarap berjumlah $18(72 \%)$ responden, dan terkecil yaitu penyewa berjumlah $1(4 \%)$ responden.

\section{Karakteristik Umur Petani Responden}

Umur seseorang menentukan prestasi kerja atau kinerja orang tersebut. Semakin tua tenaga kerja maka secara fisik akan terasa berat pekerjaannya, sehingga akan semakin turun pula prestasinya. Namun, dalam hal ini tanggung jawab semakin tua umur tenaga kerja tidak akan berpengaruh karena justru semakin berpengalaman (Suratiyah, 2015).

Tabel 5. Jumlah Petani Responden Menurut Umur

\begin{tabular}{lcc}
\hline Umur & Jumlah (Responden) & Persentase $(\%)$ \\
\hline$\leq 40$ & 4 & 16,00 \\
$41-50$ & 12 & 48,00 \\
$51-60$ & 8 & 32,00 \\
$\geq 61$ & 1 & 4,00 \\
\hline Jumlah & 25 & 100,00
\end{tabular}

Tabel 4, menunjukkan bahwa Jumlah petani responden menurut umur menunjukkan kebanyakan responden berusia 41-50 tahun dengan responden 12 (48\%) dan responden yang berusia $\geq 61$ tahun berjumlah $1(4 \%)$. Ratarata umur responden 41-60 dengan Persentase $80 \%$.

\section{Tingkat Pendidikan}

Pendidikan merupakan salah satu hal yang sangat penting bagi manusia yang merupakan bekal dalam hidupnya. Karena dengan pendidikan yang cukup seseorang akan memiliki pola pikir yang lebih maju dan berkembang. Tingkat pendidikan petani responden dapat dilihat pada Tabel 6 .

\begin{tabular}{lcc}
\multicolumn{2}{c}{ Tabel 6. Jumlah Petani Padi Sawah berdasarkan Tingkat Pendidikan } \\
\hline \multicolumn{1}{c}{ Pendidikan } & Jumlah (Responden) & Persentase $(\%)$ \\
\hline SD & 7 & 28,00 \\
SMP & 9 & 36,00 \\
SMA & 9 & 36,00 \\
\hline Jumlah & 25 & 100,00 \\
\hline Sumber: Diolah dari Data Primer 2018 &
\end{tabular}


Tabel 6, menunjukkan jumlah dan Persentase petani padi sawah berdasarkan tingkat pendidikan. Dari tabel dapat dilihat jumlah petani dengan tingkat pendidikan SMP dan SMA masing-masing berjumlah 9 responden dengan nilai Persentase (36\%) merupakan jumlah terbanyak, dan tingkat pendidikan SD hanya berjumlah 7 responden dengan nilai Persentase (28\%). Rata-rata tingkat pendidikan responden $72 \%$.

\section{Jumlah Tanggungan Keluarga}

Jumlah tanggungan keluarga bias membantu dalam penyediaan tenaga kerja. Untuk lebih jelasnya jumlah tanggungan keluarga petani. Lihat pada Tabel 7.

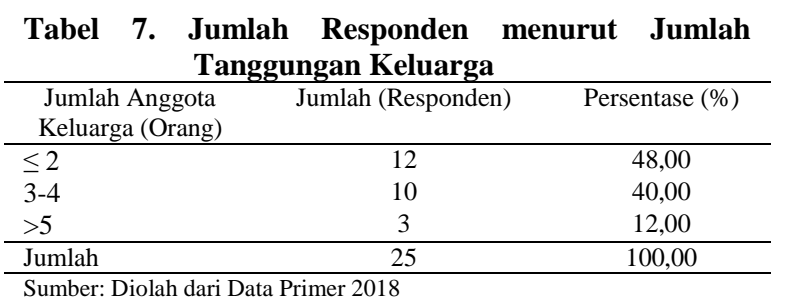

\section{Biaya Usahatani Padi Sawah}

Biaya produksi usahatani padi sawah adalah biaya yang dikeluarkan pada saat pelaksanaan usahatani padi sawah dilakukan. Biaya produksi dapat dilihat dalam Tabel 8.

Tabel 8. Biaya Produksi Usahatani Padi Sawah

\begin{tabular}{llcc}
\hline No & $\begin{array}{c}\text { Biaya } \\
\text { Produksi (Rp) }\end{array}$ & $\begin{array}{c}\text { Jumlah } \\
\text { (Responden) }\end{array}$ & Persentase (\%) \\
\hline 1. & $<5.500 .000$ & 10 & 40,00 \\
2. & $5.500 .000-8.000 .000$ & 11 & 44,00 \\
3. & $>8.000 .0000$ & 4 & 16,00 \\
\hline \multicolumn{2}{l}{ Jumlah } & 25 & 100,00 \\
\hline \multicolumn{2}{l}{ Sumber: Diolah dari Data Primer 2018 }
\end{tabular}

Tabel 8 menunjukkan bahwa biaya produksi usahatani padi sawah $\mathrm{Rp}<5.500 .000$ sebanyak 10 atau $40 \%$ responden, $\mathrm{Rp}$ 5.500.000-8.000.000 sebanyak 11 atau 44\%, dan biaya produksi > Rp 8.000.000 sebanyak 4 atau $16 \%$ responden. Biaya produksi usahatani padi sawah terkecil yang dikuasai oleh responden $>8.000 .000$, sedangkan biaya usahatani padi sawah terbesar yang dikuasai oleh responden 5.000.000-8.000.000. Ratarata biaya produksi responden sebesar $84 \%$.

\section{Pendapatan Usahatani Responden}

Pendapatan usahatani padi sawah merupakan pendapatan yang diperoleh dari proses produksi usahatani padi sawah yang diwujudkan dalam bentuk rupiah.

Tabel 9. Pendapatan Dari Usahatani Padi Sawah

\begin{tabular}{|c|c|c|c|}
\hline No & Biaya Produksi (Rp) & $\begin{array}{c}\text { Jumlah } \\
\text { (Responden) }\end{array}$ & Persentase (\%) \\
\hline 1. & $<5.000 .000$ & 10 & 40,00 \\
\hline 2. & $5.500 .000-8.000 .000$ & 11 & 44,00 \\
\hline \multirow[t]{2}{*}{3.} & $>8.000 .0000$ & 4 & 16,00 \\
\hline & Jumlah & 25 & 100,00 \\
\hline
\end{tabular}

\section{Pendapatan Selain padi}

Pendapatan selain padi sawah adalah pendapatan yang diperoleh responden selain berusaha sebagai petani padi sawah yaitu sebagai petani diluar padi sawah. Dapat dilihat pada Tabel 10.

\begin{tabular}{lcc}
\multicolumn{3}{c}{ Tabel 10. Pendapatan di luar Padi Sawah Selama 1 Tahun } \\
\hline Pendapatan (Rp) & Jumlah (Responden) & Persentase (\%) \\
\hline 0 & 12 & 48,00 \\
$1.000 .000-4.000 .000$ & 4 & 16,00 \\
$4.000 .000-8.000 .000$ & 6 & 24,00 \\
$>8.000 .0000$ & 3 & 12,00 \\
\hline Jumlah & 25 & 100,00 \\
\hline
\end{tabular}

Sumber: Diolah dari Data Primer 2018

Tabel 10 menunjukkan bahwa pendapatan diluar padi sawah yang tidak memiliki pendapatan berjumlah 12 responden dengan nilai $48 \%$, Pendapatan Rp 1.000.0004.000.000 berjumlah 4 responden dengan nilai $16 \%$, pendapatan $\mathrm{Rp} 4.000 .000-$ 8.000.000 berjumlah 6 responden dengan nilai $24 \%$, dan pendapatan tertinggi $>\mathrm{Rp}$ 8.000 .000 berjumlah 3 responden dengan nilai $12 \%$.

\section{Pendapatan Non-Pertanian}

Pendapatan non-pertanian adalah pendapatan yang diperoleh responden selain berusaha sebgai petani padi sawah yaitu sebagai buru dan lain-lain yang diluar pertanian dapat dilihat pada Tabel 11.

\begin{tabular}{|c|c|c|}
\hline Pendapatan (Rp) & Jumlah (Responden) & Persentase (\%) \\
\hline 0 & 12 & 48,00 \\
\hline $10.000 .000-40.000 .000$ & 4 & 16,00 \\
\hline$>40.000 .000-80.000 .000$ & 6 & 24,00 \\
\hline Jumlah & 25 & 100,00 \\
\hline
\end{tabular}


Tabel 11 menunjukkan pendapatan responden diluar pertanian yang tidak memiliki pendapatan diluar pertanian berjumlah 11 responden dengan nilai Persentase $44 \%$, pendapatan $\mathrm{Rp}$ 10.000.000-40.000.000 dengan jumlah responden 10 dengan nilai $40 \%$, dan pendapatan tertinggi $>\mathrm{Rp} 40.000 .000-$ 80.000 .000 berjumlah 4 responden dengan Persentase $16 \%$.

\section{Total Pendapatan Keluarga}

Total pendapatan keluarga responden dalam 1 tahun dinyatakan dalam bentuk rupiah. Total pendapatan keluaraga merupakan hasil seluruh pendapatan bersih dari pendapatan usahatani padi sawah dan pendapatan diluar padi sawah dapat dilihat pada Tabel 12.

Tabel 12. Total pendapatan Keluarga selama 1 Tahun

\begin{tabular}{lcc}
\hline $\begin{array}{l}\text { Pendapatan } \\
(\mathrm{Rp})\end{array}$ & $\begin{array}{c}\text { Jumlah } \\
\text { (Responden) }\end{array}$ & Persentase (\%) \\
\hline$<10.000 .000$ & 7 & 28,00 \\
$10.000 .000-$ & 8 & 32,00 \\
30.000 .000 & & \\
$30.000 .000-$ & 9 & 36,00 \\
80.000 .000 & & 4,00 \\
$>80.000 .0000$ & 1 & 100,00
\end{tabular}

Sumber: Diolah dari Data Primer 2018

Pendapatan keluarga selama satu tahun terkecil yang dikuasai oleh responden 1 (4\%), sedangkan pendapatan keluarga terbesar yang dikuasai oleh responden 9 (36\%). Rata-rata pendapatan keluarga selama satu tahun $96 \%$.

\section{Kontribusi Dari Usahatani Padi Sawah Terhadap Pendapatan Keluarga Responden}

Kontribusi yang dimaksud dalam penelitian ini adalah sumbangan dari usahatani padi sawah yang dilakukan di daerah penelitian sebanyak 25 reponden petani yang berprofesi sebagai petani padi sawah. Usahatani padi sawah di Kelurahan Taratara Satu diusahakan oleh para petani untuk memperoleh pendapatan. Selain usahatani padi sawah petani di Kelurahan Taratara Satu juga memproleh pendapatan dari usahalain yaitu wirausaha, burutani, PNS dan lain sebagainya baik yang dikerjakan oleh kepalah keluarga atau anggota keluarga. Pendapatan total keluarga disini dapat dihitung dari pendapatan usahatani padi sawah dan pendapatan diluar usahatani padi sawah. Untuk menghitung besarnya kontribusi dari usahatani padi sawah terhadap pendapatan keluarga dapat menggunankan rumus:

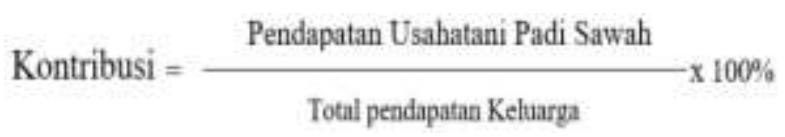

Tabel 13 menunjukkan bahwa kontribusi usahatani padi sawah hanya dibawah $50 \%$ yaitu sekitar $22.29 \%$ saja atau dapat disimpulkan tidak berkontribusi bagi pendapatan keluarga di Kelurahan Taratara Satu.

Tabel 13. Kontribusi Usahatani Padi Sawah Terhadap Pendapatan Keluarga

\begin{tabular}{lcc}
\hline $\begin{array}{l}\text { Sumber } \\
\text { Pendapatan }\end{array}$ & $\begin{array}{c}\text { Jumlah } \\
\text { Pendapatan } \\
\text { (Rp/Tahun) }\end{array}$ & Persentase (\%) \\
\hline $\begin{array}{l}\text { Usahatani padi } \\
\text { Usahatani Selain }\end{array}$ & $\begin{array}{l}\text { 2.519.488,98 } \\
\text { padi }\end{array}$ & 22,29 \\
Non-pertanian & $16.330 .680,00$ & 11,77 \\
\hline Jumlah & $24.764 .168,98$ & 65,94 \\
\hline
\end{tabular}

Sumber: Diolah dari Data Primer 2018

\section{KESIMPULAN DAN SARAN}

\section{Kesimpulan}

Kesimpulan dari penelitian ini yaitu kontribusi usahatani padi sawah memberikan kontribusi yang sebanyak 22,29\%. Hal tersebut dipengaruhi oleh luas lahan, harga jual, dan biaya. 


\section{Saran}

Usahatani padi sawah di Kelurahan Taratara Satu, layak untuk diusahakan, oleh karena itu pemerintah dan petani harus bekerja sama dalam meningkatkan produksi usahatani padi sawah, agar usahatani padi sawah tidak hanya diusahakan namun juga lebih dikembangkan. Tindak lanjut dari penelitian ini diperlukan agar mendapatkan informasi dan kajian yang lebih lengkap menyangkut jumlah pengeluaran rumah tangga petani padi sawah, status pemilikan rumah tinggal dan luas pemilikan lahan non padi sawah.

\section{DAFTAR PUSTAKA}

Hatidja, M. 2008 Analisis Pendapatan Usahatani salak (Studi Kasus Desa Pangu Kecamatan Ratahan). Skripsi. Fakultas Pertanian. Manado.

Hernanto, F, 1993. Ilmu Usahatani. Departemen Sosial Ekonomi,IPB. Bogor.

Isaskar, Riyanti. 2014. Modul 1. Pendahuluan :Pengantar Usahatani Laboratorium Analisis dan Manajemen Agribisnis. Fakultas Pertanian Universitas Brawijaya.
Kantor Kelurahan Taratara Satu. Data Pokok Kelurahan Bulan Desember 2016.

Lewa, 2014. Kontribusi Tenaga Kerja Wanita Tani Pada Usahatani Padi Sawah Di Desa Wuliwali Kecamatan Wauponggo Kabupaten Nagekeo. Fakultas Pertanian. Universitas Hasanudin. Makasar.

Pratama A. 2011. " Pentingnya Pertanian Bagi Perekonomian Di Indonesia". http//.www.adventuspratama.blogsp ot.com.

Soedjana, Tjeppy D. 2007. Sistem Usahatani Terintegrasi TanamanTernak Sebagai Respons Petani Terhadap Faktor Resiko Jurnal Litbang pertanian. Badan Penelitian dan Pengembangan Pertanian. Jakarta.

Sukirno, 2006. Ekonomi Pembangunan. Proses, Masalah dan Kebijakan, Kencana Prenada Media Group.

Suratiyah. 2006. Ilmu Usahatani. Penebar Swadayah. Jakarta. 